\title{
TRADISI BAHILAH PADA MASYARAKAT BANJAR PAHULUAN
}

\author{
M. Zainal Abidin*
}

\begin{abstract}
Tulisan ini bermaksud mengekplorasi suatu tradisi yang biasa dilakukan dalam masyarakat Banjar Pabuluan dalam upacara kematian, yakni bahilah. Tradisi ini tetap lestari sebagai bagian ritual yang dilakukan pada masyarakat di sana. Fenomena ini unik mengingat bahilah dari sudut pandang mazhab syafi'ie yang notabene mazhab utama yang diikuti oleh masyarakat di sana adalah sesuatu yang diharamkan. Namun, dengan alasan mazhab Hanafi membolebkan, maka praktek ini kemudian dilestarikan. Fenomena perpindahan mazhab inilah yang kemudian menjadi isu menarik untuk dikupas. Karena ternyata dalam keberagamaan masyarakat Banjar, khususnya di pabuluan relatif ada fleksibilitas ketika berbdapan dengan sesuatu yang mendasar dalam kebudayaan Banjar, yakni penghormatan dan kebaktian terhadap lelubur. Inilah sejatinya ajaran dasar keyakinan lokal yang tetap ada, meski kemudian datang agama-agama luar seperti Hindu, Budha, Kristen, dan Islam.
\end{abstract}

Kata kunci: tradisi bahilah, pergeseran paradigma, sosiologi pengetahuan

\section{Pendahuluan}

Bagi umat Islam, peristiwa kematian adalah suatu momentum yang dianggap sangat penting dan sakral, dan karenanya perlu diupacarakan. Kematian merupakan fase yang harus dilewati oleh setiap manusia dan dipandang sebagai pintu satu-satunya untuk menuju kehidupan yang sebenarnya, yakni alam akherat, tempat manusia mendapatkan balasan atau ganjaran atas segala tindakannya selama hidup di dunia.

Sakralitas terhadap peristiwa kematian ini juga terdapat pada masyarakat Banjar di Kalimantan Selatan, khususnya kalangan tradisionalis. ${ }^{1}$ Bentuk

\footnotetext{
*Pengajar pada Fakultas Ushuluddin IAIN Antasari Banjarmasin. Email: zayn@scientist.com
} 
sakralisasi terhadapnya dapat dilihat dari banyaknya prosesi ritual yang harus dilakukan dalam rangka melepaskan si mayyit ke tempat peristirahatannya di alam kubur. Salah satu bagian dari prosesi upacara kematian yang sering dilaksanakan adalah tradisi babilah dalam rangka kematian, yang ditujukan untuk membebaskan tanggungjawab si mayyit atas berbagai kewajiban yang tidak ditunaikannya pada saat hidup di dunia. Kawasan yang marak melaksanakan praktek babilah terdapat di Hulu Sungai yang biasa disebut dengan Banjar Pahuluan atau kawasan Banua Enam. ${ }^{2}$

Tradisi babilah sendiri di kalangan umat Islam di Kalimantan Selatan menjadi perdebatan yang belum tuntas. Bagi kalangan modernis (baca: Muhammadiyah), tradisi babilah ini diabaikan karena dianggap tidak memiliki dasar yang kuat dari Alquran dan Hadis. Sementara itu di kalangan tradisionalis, yang notabene mayoritas mengikuti Mazhab Syafi'i juga menjadi problem, karena dalam Mazhab Syafi'i sendiri praktek bahilab termasuk dilarang. ${ }^{3}$ Tradisi babilab ini umumnya hanya didasarkan pada Mazhab Hanafi, yang memang membolehkan adanya bilah, yang kemudian dikembangkan oleh beberapa ulama lokal yang cukup kharismatik, sehingga aspek lokalitas dari praktek ini cukup dominan. $^{4}$

Terlepas dari polemik yang menyertainya, ternyata tradisi babilah sejauh amatan penulis, berkembang cukup pesat pada masyarakat Banjar Pahuluan, bahkan terkesan setengah wajib untuk dilaksanakan dalam setiap upacara kematian. Sementara di kawasan lain di Kalimantan Selatan, praktek ini sudah mulai ditinggalkan bersamaan dengan meninggalnya para sesepuh yang

${ }^{1}$ Kalimantan Selatan adalah salah satu provinsi dari empat provinsi yang ada di Kalimantan dengan ibu kota Banjarmasin. Luas provinsi ini $41.467,75 \mathrm{~km}^{2}$, yang meliputi 2 Kota dan 11 Kabupaten. Suku utama di Provinsi ini adalah suku Banjar. Menurut Alfani Daud, Islam telah menjadi ciri dan identitas masyarakat Banjar sejak berabad-abad yang silam. Lihat Alfani Daud, Islam dan Masyarakat Banjar: Deskripsi dan Analisa Kebudayaan Banjar, (Jakarta: RajaGrafindo Persada, 1997), h. 504.

${ }^{2}$ Dewasa ini ada enam kabupaten yang termasuk kawasan Hulu Sungai, dan disebut Banua Enam, yaitu Hulu Sungai Tengah (HST), Hulu Sungai Utara (HSU), Hulu Sungai Selatan (HSS), Tabalong, Balangan, dan Tapin.

${ }^{3}$ Lihat H. M. Zaki Mubarak, Praktek Babilah dalam Pembayaran Fidyah di Kalimantan Selatan dalam Perspektif Mazhab Syafi'i, (Banjarmasin: PPs IAIN Antasari, 2010), h. 150

${ }^{4}$ Ada beberapa literatur lokal yang sering dipegangi dalam praktek babilab di Kalimantan Selatan, yaitu tulisan Muhammad Khalid, al Faidhah al Ilabiyah bagi Isqath ash-Shalah, (Singapura: al-Ahmadiyah, cet. I, 1352 H/1935 M); Abdul Aziz Syarbaini, Dhiyauddin al-Islami, (Kandangan: Sahabat, 1418 H); Abu Daudi, Penyelenggaraan Jenazah, (Martapura: Yayasan Pendidikan Islam Dalam Pagar (YAPIDA), 1997). 
umumnya menjadi pelaku dalam praktek bahilah, dan tidak mengalami regenerasi. ${ }^{5}$

Melihat fakta bahwa umumnya masyarakat Banjar, khususnya di Pahuluan termasuk yang relative lebih taat dan fanatik dalam bermazhab, maka kenyataan mereka "menabrak" rambu-rambu mazhab Syafi'i yang mengharamkan praktek babilah, dan kemudian berpaling ke mazhab Hanafi yang notabene bukan referensi utama dalam bermazhab menjadikan tradisi babilah yang dilaksanakan dalam upacara kematian tersebut menjadi sesuatu yang menarik untuk dikaji secara mendalam.

Tampaknya ada sesuatu mendasar yang lebih dari sekadar persoalan perpindahan bermazhab yang perlu diungkap dari praktek ini. Kenyataan ini menarik apabila ditinjau dari perspektif sosiologi pengetahuan, khususnya pada kenyataan adanya fakta pergesaran paradigma bermazhab. ${ }^{6}$ Dalam hal ini, mazhab syafi'i dapat dipandang sebagai sebuah paradigma (normal science), yang diikuti oleh pengikutnya. Namun dalam hal tertentu (tradisi babilab), ada aspek yang tidak mereka peroleh dalam paradigma lama mazhab yang mereka ikuti, akhirnya mereka berpindah ke mazhab yang lain yang memungkinkan untuk itu dengan modifikasi tertentu sesuai dengan tradisi lokal yang berkembang. Peristiwa ini oleh Kuhn disebut dengan revolusi ilmu.

Penggunaan pendekatan sosiologi pengetahuan dalam melihat sebuah fenomena atau praktek keagamaan relatif baru. Fokus pendekatan ini sendiri bukanlah untuk melihat persoalan halal atau haram sebagaimana lazimnya pendekatan normatif, tetapi lebih memfokuskan kepada konstruksi pengetahuan yang dimiliki masyarakat. Di sini, tradisi bahilah dalam upacara kematian pada Masyarakat Banjar Pahuluan, yang mengindikasikan adanya perpindahan mazhab dari Syafi'i kepada Hanafi menjadi persoalan yang hendak dielaborasi secara lebih mendalam.

Ada beberapa pokok masalah yang diangkat dalam tulisan ini, yakni: sekitar prosesi ritual praktek babilah, faktor-faktor yang mendasari pelaksanaan

\footnotetext{
${ }^{5}$ Mengutip pernyataan Prof. Dr. H.Asywadie Syukur pada seminar proposal tesis yang diselenggarakan di Pascasarjana pada sabtu, 13 Juni 2009.

${ }^{6}$ istilah paradigma merujuk kepada pandangan Thomas Kuhn dalam "the Structure of Scientific Revolutions", yakni bahwa realitas sosial itu dibangun atas mode of thought atau mode of inquiry tertentu yang pada gilirannya akan menghasilkan mode of knowing tertentu pula. Dalam hal ini, dinyatakan Kuhn juga bahwa ilmu-ilmu yang ada sudah menjadi sebuah paradigma (disebut normal science) mengalami krisis, lalu timbul revolusi ilmu. Kemudian ilmu yang memberontak itu menjadi normal science, menjadi sebuah paradigma baru. Lihat Thomas Kuhn, the Structure of Scientific Revolutions, (Chicago: The University of Chicago Press, 1970), hal. 10-11.
} 
babilah, dan terakhir ulasan mengapa masyarakat Banjar Pahuluan menjadikan praktek bahilah sebagai bagian dari upacara kematian yang tetap dipertahankan meski itu di luar mainstream mazhab Syafi'i yang umumnya dipegangi oleh mereka.

Kajian atau penelitian terhadap praktek babilah di Kalimantan Selatan, yang melihat dari sisi latar belakang munculnya motivasi-motivasi yang menyertai pelaksanaannya, dan ditelaah dari perspektif sosiologi pengetahuan sepanjang yang penelusuran peneliti belum pernah dilakukan.

Beberapa penelitian yang ada membahas tentang praktek bahilah yang telah dilakukan hanya terkait dengan deskripsi singkat sebagai bagian dari pembahasan yang lebih umum baik mengenai ritual kematian ataupun kebudayaan Banjar. Sebagai misal, penelitian oleh tim peneliti dari balai penelitian IAIN Antasari yang diketuai oleh H. M. Yusran Asmuni pada tahun 1992 membahas mengenai ritual kematian di kecamatan Barabai dan Batang Alai Selatan yang salah satunya mengenai praktek bahilah dalam rangka membayarkan macam-macam kafarat dan fidyah bagi si mayat.

Selanjutnya penelitian yang dilakukan oleh Alfani Daud untuk disertasinya yang berjudul Islam dan Masyarakat Banjar: Deskripsi dan Analisa Kebudayaan Banjar, ada pada satu bagian pembahasan yang menyinggung mengenai adat babilah dalam upacara kematian pada masyarakat Banjar di Kalimantan Selatan.

Penelitian lainnya dilakukan oleh Zaki Mubarak untuk kepentingan penyusunan tesis yang berjudul Praktek Bahilah dalam Pembayaran Fidyah di Kalimantan Selatan dalam Perspektif Mazhab Syafi'i. Penelitian yang disebutkan terakhir ini lebih mendalam dalam mengangkat persolan babilah dibandingkan dua penelitian sebelumnya yang hanya menyinggung sedikit tentang praktek bahilah secara deskriptif pada aspek prosedurnya tanpa ada memberikan analisis tertentu. Meski demikian penelitian Zaki lebih berkutat pada aspek hukum Islam dengan fokus pada mazhab Syafi'i. Temuan menarik dari penelitian ini bahwa Imam Syafi'i, Imam Malik, dan Ahmad bin Hanbal juga ulama-ulamanya yang mutaqaddimin mengharamkan semua bentuk bilah yang tujuannya membatalkan hukum atau hak orang lain. Sehingga praktek babilah dalam pembayaran fidyah yang dipraktekkan di beberapa daerah di Kalimantan Selatan tidak dapat dinisbatkan kepada mazhab apapun.

Berangkat dari sini, maka kajian tentang praktek babilah dalam upacara kematian pada masyarakat Banjar Pahuluan yang dilihat dari perspektif sosiologi pengetahuan merupakan kajian yang baru, terlebih apabila itu 
difokuskan pada persoalan perpindahan mazhab yang terjadi pada masyarakat Banjar Pahuluan di Kalimantan Selatan.

\section{Tradisi Bahilah dalam Masyarakat Banjar Pahuluan}

Di daerah Banjar Bagian Hulu Sungai, atau lazim disebut Banjar Pahuluan, praktek bahilah menjadi bagian yang tidak dipisahkan dari ritual kematian yang dilakukan umat Islam. Dalam ritual kematian tersebut, praktek bahilah dilakukan dalam konteks pembayaran fidyah agar orang yang meninggal terbebas dari beban-bena dosa akibat pelanggaran yang mungkin dilakukannya ketika masih hidup di dunia.

Tradisi babilah sebagai bagian dari ritual kematian yang harus dilaksanakan pada masyarakat Banjar pahuluan tidak dapat diidentifikasi secara jelas kapan pertama kali dilakukan. Bukti tertulis yang dapat dilacak hanya berupa buku atau risalah karya ulama setempat yang menjadi pegangan bagi masyarakat dalam melaksanakan praktek bahilah. Di antara risalah dimaksud yaitu risalah yang disusun oleh K.H. Abdul Aziz Syarbaini dari Kandangan (Hulu Sungai Selatan), K.H. Muhammad Khalid dari Amuntai (Hulu Sungai Utara), K.H. As'ad dari Barabai (Hulu Sungai Tengah), dan K.H. Abu Daudi dari (Banjar).

Dari risalah-risalah tersebut yang paling tua adalah risalah yang dikarang oleh K.H. Muhammad Khalid dari Amuntai. Risalah yang ditulis dengan tulisan Arab-Melayu dan diberi nama "al-Faidhah al-Ilabiyah bagi Isqąth ash-Shalab" pertama kali dicetak oleh percetakan al-Ahmadiyah, Jln. Sultan, no. 82, Singapura pada tahun $1353 \mathrm{H}$ bertepatan dengan tahun 1935 M. Ini berarti bahwa praktik babilab di Kalimantan Selatan sudah ada sejak sebelum tahun $1935 \mathrm{M}^{7}$

Praktik babilah ini biasanya dilaksanakan di rumah si mayyit sendiri atau di rumah tetangganya. Pada umumnya dilaksanakan sebelum penguburan, dengan harapan bahwa sebelum si mayyit berada dalam kubur, maka segala kewajiban-kewajibannya telah lunas terbayar. Namun, kadang-kadang ada juga yang melaksanakannya sesudah penguburan, bahkan beberapa hari kemudian dengan pertimbangan situasi dan kondisi.

Secara umum, praktek bahilah dilksanakan dengan dengan bertaqlid kepada mazhab Hanafi. Dalam hal ini, ahli waris menyiapkan sejumlah barang berharga atau perhiasan seperti emas. Barang berharga ini pada umumnya disebut "ungkal" dan biasanya dibungkus menjadi satu dengan kain atau 
dimasukkan ke dalam dompet. Ungkal ini berfungsi sebagai pengganti sejumlah beras yang harus dibayarkan. Jika ahli waris tidak mempunyai ungkal, ia dapat meminjam atau berutang kepada orang lain atau kepada pihak yang diamanahi oleh ahli waris untuk melakukan hilah. Yang terakhir ini biasanya memiliki ungkal yang khusus disediakan untuk keperluan bilah. Ungkal pinjaman itu ada serah terimanya sehingga sepertinya memang milik ahli waris al-marhum. Selain ungkal, ahli waris juga menyediakan sejumlah amplop berisi uang lelah dan biaya transport bagi para pelaksana hilah. ${ }^{8}$

\section{Perspektif Sosiologi Pengetahuan terhadap Praktek Bahilah}

Perspektif sosiologi pengetahuan menjadi pilihan dalam 'membaca' permasalahan-permasalahan terkait bahilah. Sosiologi pengetahuan merupakan cabang sosiologi yang mempelajari hubungan timbal balik antara pengetahuan dan masyarakat. Ia berupaya menghubungkan ide-ide dengan realitas masyarakat dan mengkaji setting historis di mana ide-ide itu diproduksi dan diterima. Sosiologi pengetahuan juga dipandang sebagai metode yang positif bagi penelaahan hampir setiap fase pemikiran manusia. ${ }^{9}$

Salah satu tokoh sosiologi pengetahuan, Karl Mannheim, menyatakan bahwa sosiologi pengetahuan merupakan disiplin yang berusaha untuk menemukan sebab-sebab sosial dari suatu kepercayaan masyarakat, yang kemudian dilawankan dengan pikiran-pikiran masyarakat tentang sebab-sebab sosial itu. Bagi Mannheim, pengetahuan manusia tidak bisa lepas dari subjektifitas dan kondisi psikologis individu yang mengetahuinya. Pengetahuan dan eksistensi adalah dua hal yang tidak bisa dipisahkan satu sama lain. Semua pengetahuan dan kepercayaan adalah produk proses sosial politik. Untuk itu ada satu teori penting dari Mannheim yang disebutnya sebagai teori relasionisme. Teori ini menyatakan bahwa setiap pemikiran selalu berkaitan dengan keseluruhan struktur sosial yang melingkupinya. ${ }^{10}$

Pada prinsipnya, sosiologi pengetahuan senantiasa bersikap kritis terhadap pengetahuan. Ia mempelajari ide-ide dalam konteks sosio-historisnya, konstruksi sosial pengetahuan, konteks sosio-historis ide-ide, asal-usul ideologis pengetahuan, akar-akar pengetahuan dalam pengalaman kelas, ras,

${ }^{8}$ Lihat juga H. M. Zaki Mubarak, Praktek Babilah...., h. 27

${ }^{9}$ Lihat Peter L. Berger dan Thomas Luckmann, Tafsir Sosial atas Kenyataan, Terj. Hasan Basari, (Jakarta: LP3ES, 1990), hlm. 13.

${ }^{10}$ Karl Mannheim, Ideologi dan Utopia: Menyingkap Kaitan Pikiran dan Politik, Terj. F. Budi Hardiman, (Yogyakarta: Kanisius, 1991), hlm. 306-307. 
generasi, gender, dan lain-lain. Oleh karena itu, sosiologi pengetahuan menegasikan konsepsi pengetahuan yang non-kontekstual atau ahistoris. ${ }^{11}$

Salah satu tugas pokok sosiologi pengetahuan adalah menjelaskan adanya dialektika diri (self) dengan dunia sosio-kultural. Dialektika itu berlangsung dalam suatu proses dengan tiga "momen" simultan, yakni eksternalisasi (penyesuaian diri dengan dunia sosio-kultural sebagai produk manusia), objektivasi (interaksi sosial dalam dunia intersubjektif yang dilembagakan atau mengalami proses institusionalisasi), dan internalisasi (individu mengidentifikasi diri dengan lembaga-lembaga sosial atau organisasi sosial tempat individu menjadi anggotanya. Kemandegan dari teori-teori sosiologi selama ini karena hanya memperhatikan salah satu momen dialektis itu dan kurang melihat hubungan atau interplay antara ketiga momen dialektis itu. ${ }^{12}$

Dalam konteks tulisan ini, sosiologi pengetahuan ini akan dipergunakan terutama sebagai pisau analisis dalam membedah fenomena perpindahan masyarakat Banjar Pahuluan dari mazhab Syafi'i ke mazhab Hanafi, khususnya pada praktek keagamaan berupa tradisi babilah dalam upacara kematian yang berlaku pada masyarakat Banjar Pahuluan.

Dalam kajian sosiologi ilmu pengetahuan, sering dinyatakan bahwa pemikiran seorang tokoh tidaklah berangkat dari ruang yang kosong (creatio ex nibilo), tetapi sangat dipengaruhi oleh banyak faktor seperti latar belakang pendidikan, agama, ideologi, budaya dan sebagainya. Berikutnya, ilmu pengetahuan yang dihasilkannya pun tidaklah kosong dari nilai-nilai atau kepentingan tertentu. Nilai atau kepentingan ini tidak semata terkait pada bidang ilmu-ilmu sosial humaniora, tetapi bahkan juga mencakup ilmu-ilmu alam yang selama ini dianggap netral.

Dalam karyanya Knowledge and Human Interest Habermas mengemukakan pemahaman perkembangan ilmu pengetahuan dan kepentingan manusia. ${ }^{13}$ Menurutnya ada tiga dasar wilayah kepentingan manusia yang menghasilkan ilmu pengetahuan. Wilayah ini menentukan kategori-kategori yang kemudian dimaknai sebagai ilmu pengetahuan (knowledge) yang disebut 'knowledge constitutive', yakni penentuan model-model penemuan ilmu pengetahuan dan klaim-klaim yang dapat diterima. Wilayah ini membatasi kepentingan kognitif

\footnotetext{
${ }^{11}$ Lihat Muhyar Fanani, Metode Studi Islam: Aplikasi Sosiologi Pengetabuan sebagai Cara Pandang, (Yogyakarta: Pustaka Pelajar, 2008), hlm. 53.

${ }^{12}$ Frans M. Parera, "Menyingkap Misteri Manusia sebagai Homo Faber", pengantar dalam Peter L. Berger dan Thomas Luckmann, Tafsir Sosial atas Kenyataan, hlm. xx.

${ }^{13}$ Lihat Jurgen Habermas, Knowledge and Human Interest, (Boston: Beacon Press, 1971).
} 
atau wilayah pembelajaran (learning domains), dan latar belakang dalam aspekaspek yang berbeda dari eksistensi sosial, kerja, interaksi dan kekuasaan. ${ }^{14}$

Ketiga wilayah kepentingan itu mencakup ilmu-ilmu alam, ilmu-ilmu historis-hermeneutis, dan ilmu-ilmu kritis. Dalam ilmu alam yang berikhtiar menemukan hukum alam, pada akhirnya memunculkan upaya penguasaan teknis atas proses-proses yang dianggap obyektif. Pada ilmu historishermeneutis tidak disusun secara deduktif dengan acuan kontrol teknis, tapi yang dilakukannya adalah menafsirkan teks dengan kepentingan mencapai saling pengertian dan konsensus. Sedangkan pada ilmu-ilmu kritis yang dikandungnya adalah kepentingan kognitif emansipatoris yang dilakukan lewat jalan refleksi diri seorang ilmuwan. ${ }^{15}$ Dengan demikian Habermas kemudian menampik asumsi banyak kalangan tentang ilmu pengetahuan yang benarbenar bebas nilai (free value) dengan mengatakan bahwa pengetahuan itu tidak mungkin berdiri tanpa kepentingan apapun, walaupun tetap diakuinya bahwa pengetahuan itu tidak boleh membiarkan subyektivitas mendominasi.

Prinsip bebas nilai dalam ilmu pengetahuan itu menafikan adanya "historisisme" yang sangat menentukan bagaimana konstruksi atas pengetahuan itu. Max Scheler dan Karl Mannheim, dari aliran sosiologi pengetahuan misalnya, juga menentang ide mengenai ilmu-ilmu sosial yang bebas nilai. Keduanya menyatakan bahwa pikiran, bahkan pikiran logis para ilmuwan sekalipun, dibentuk secara historis dan itu, baik disadari atau tidak, sedang merefleksikan kebudayaan mereka sendiri dan perspektif sosial yang mereka adopsi. Seorang ilmuwan memang harus mengatasi prasangkaprasangka mereka dengan memperbaiki kadar kualitas pembacaan mereka atas realitas, dengan berpangkal pada obyektivitas, tapi pada saat yang sama mereka harus mengklarifikasi asumsi-asumsi yang mendasar, memahami lokasi-lokasi sosial mereka sendiri dalam masyarakat, dan juga secara kritis mempertanyakan cita-cita sosial yang ada di masyarakat. ${ }^{16}$ Jadi, konstruksi berpikir seorang ilmuwan tidak bisa terlepas dari konteks historisnya, yang itu kemudian menuntut dirinya mampu memahami nilai-nilai yang terkandung di dalamnya.

\footnotetext{
${ }^{14}$ Lihat "The Critical Theory of Jurgen Habermas", dalam bttp://physicsed.buffalostate. edu/danowner/habcritthy.html. (diakses pada 12 September 2006).

${ }^{15}$ Lihat F. Budi Hardiman, Menuju Masyarakat Komunikatif: Ilmu, Masyarakat dan Politik Menurut Jurgen Habermas, (Yogyakarta: Kanisius, 1993), hal. 8-10.

${ }^{16}$ Gregory Baum, Agama dalam Bayang-Bayang Relativisme, penerjemah A. Murtajib Chaeri dan Masyhuri Arow, (Yogyakarta: Tiara Wacana dan Sisiphus, 1999), hal. 23-24.
} 
Praktek bahilah yang berkembang dan dipelihara dalam tradisi masyarakat Pahuluan, khususnya yang beraliran tradisional tidak dapat dilepaskan dari tradisi yang melekat pada masyarakat Banjar dan umumnya masyarakat di Nusantara untuk senantiasa mengedepankan penghormatan dan kebaktian pada leluhur. Tradisi ini begitu kental melekat dalam kebudayaan masyarakat ini, sehingga agama pun yang masuk ke Nusantara mesti mampu beradaptasi dengan kondisi ini. Kebaktian terhadap orang tua ini tidak semata berlaku pada orang tua yang masih hidup, bahkan terhadap orang yang sudah meninggal pun tetap dipelihara tradisi tersebut. Bentuk kebaktian yang umum dilakukan yaitu dengan mengirimi bacaan-bacaan tertentu, baik yang sifatnya mingguan, yang dilakukan pada setiap malam jum'at, sendirian atau berjamaah, maupun yang sifatnya tahunan seperti tradisi haulan.

Khusus berkaitan dengan praktek bahilah, ada dilema tersendiri bagi masyarakat Banjar yang notabene menganut mazhab Syafi'i dalam fikih. Sebagaimana dikemukakan sebelumnya Syafi'i termasuk yang tidak membolehkan adanya bilah dalam praktek beragama. Tidak adanya ruang untuk melaksanakan hilah yang merupakan salah satu sarana untuk melakukan kebaktian kepada leluhur menjadikan mereka mengambil pendapat pada mazhab Hanafi yang membolehkan dilakukannya praktek hillah. Di sini terlihat padanya peralihan dalam bermazhab agar tetap dapat melestarikan proses kebaktian pada leluhur.

Dengan menggunakan teori pergeseran paradigma dapat diuraikan, bahwa mazhab fikih dapat diposisikan sebagai sebuah paradigma. Umat Islam Banjar mempraktekkan keberagamaan mereka pada mazhab ini. Para tuan guru yang menjadi tokoh agama setempat dapat dikelompokkan sebagai saintis yang bekerja dalam lingkup mazhab Syafi'i. Dikarenakan kebuntuan mereka dalam melihat peluang pada mazhab Syafi'i dalam melakukan kebaktian kepada leluhur berupa praktek hilah, maka terjadilah pergeseran paradigma dalam bermazhab.

Namun, pergeseran ini belum sampai kemudian melahirkan mazhab baru, karena relatif faktor-faktor yang mendukung ke arrah itu belum memungkinkan. Pergeseran ini semakin menguatkan teori bahwa pada dasarnya model keberagamaan dalam masyarakat nusantara tidak dapat dilepaskan dari penghormatan yang kuat terhadap leluhur. Ini adalah esensi yang kemudian tidak lebur dengan datangnya berbagai ajaran agama yang masuk ke kawasan ini. 


\section{Penutup}

Tradisi ini tetap lestari sebagai bagian ritual yang dilakukan pada masyarakat di sana. Fenomena ini unik mengingat babilah dari sudut pandang mazhab syafi'ie yang notabene mazhab utama yang diikuti oleh masyarakat di sana adalah sesuatu yang diharamkan. Namun, dengan alasan mazhab Hanafi membolehkan, maka praktek ini kemudian dilestarikan. Fenomena perpindahan mazhab inilah yang kemudian menjadi isu menarik untuk dikupas. Karena ternyata dalam keberagamaan masyarakat Banjar, khususnya di pahuluan relatif ada fleksibilitas ketika berhdapan dengan sesuatu yang mendasar dalam kebudayaan Banjar, yakni penghormatan dan kebaktian terhadap leluhur. Inilah sejatinya ajaran dasar keyakinan lokal yang tetap ada, meski kemudian datang agama-agama luar seperti Hindu, Budha, Kristen, dan Islam. 


\section{Daftar Pustaka}

Baum, Gregory, Agama dalam Bayang-Bayang Relativisme, terj. A. Murtajib Chaeri dan Masyhuri Arow, Yogyakarta: Tiara Wacana dan Sisiphus, 1999.

Daud, Alfani, Islam dan Masyarakat Banjar, Deskripsi dan Analisa Kebudayaan Banjar, Raja Grafindo Persada, Jakarta, cet. I, 1997

Daudi, Abu, Penyelenggaraan Jenazah, Martapura: Yayasan Pendidikan Islam Dalam Pagar (YAPIDA), 1997.

Frans M. Parera, "Menyingkap Misteri Manusia sebagai Homo Faber", pengantar dalam Peter L. Berger dan Thomas Luckmann, Tafsir Sosial atas Kenyataan, Terj. Hasan Basari, (Jakarta: LP3ES, 1990)

Habermas, Jurgen, Knowledge and Human Interest, Boston: Beacon Press, 1971.

Hardiman, F. Budi, Menuju Masyarakat Komunikatif: Ilmu, Masyarakat dan Politik Menurut Jurgen Habermas, Yogyakarta: Kanisius, 1993.

Khalid, Muhammad, al Faidhah al Ilahiyah bagi Isqath ash-Shalah, Singapura: alAhmadiyah, cet. I, $1352 \mathrm{H} / 1935 \mathrm{M}$

Kuhn, Thomas, the Structure of Scientific Revolutions, (Chicago: The University of Chicago Press, 1970).

L. Berger, Peter dan Thomas Luckmann, Tafsir Sosial atas Kenyataan, Terj. Hasan Basari, Jakarta: LP3ES, 1990

Mannheim, Karl, Ideologi dan Utopia: Menyingkap Kaitan Pikiran dan Politik, Terj. F. Budi Hardiman, Yogyakarta: Kanisius, 1991

Mubarak, H. M. Zaki, Praktek Bahilah dalam Pembayaran Fidyah di Kalimantan Selatan dalam Perspektif Mazhab Syafi'i, Banjarmasin: PPs IAIN Antasari, 2010.

Muhyar Fanani, Metode Studi Islam: Aplikasi Sosiologi Pengetahuan sebagai Cara Pandang, Yogyakarta: Pustaka Pelajar, 2008.

Syarbaini, Abdul Aziz, Dhiyauddin al-Islami, Kandangan: Sahabat, 1418 H. 
